\title{
Trends in Daily Rainfall Intensity Over Israel 1950/1-2003/4
}

\author{
Yizhak Yosef $^{1}$, Hadas Saaroni ${ }^{*}, 2$ and Pinhas Alpert ${ }^{1}$ \\ ${ }^{I}$ Department of Geophysics and Planetary Sciences, Tel-Aviv University, Israel \\ ${ }^{2}$ Department of Geography and the Human Environment, Tel-Aviv University, Israel
}

\begin{abstract}
The study focuses on long-term trends of daily rainfall in Israel as a function of their intensity in order to identify potential trends in rainfall extremity. The study period is the rainy season, October-May between 1950/1 and 2003/4. For the total rainfall, an increased trend is shown across Israel, especially for the central and southern regions, though non-significant. Daily rainfall intensity showed non-significant trends of increase in the heavy rainfall at the center and south and decrease at the north. The light to moderate rainfall trends increased in the north while they decreased at the center and south. Trends are significantly correlated with known teleconnection patterns, especially the East AtlanticWestern Russia and the North Sea-Caspian Sea patterns. Positive trends toward heavier rainfall are noted in Israel, which are significant in several specific locations. This finding has to be carefully followed since the region is a climatic border subjected to severe water shortage and is predicted to dry-up in most global warming scenarios.
\end{abstract}

Keywords: Rainfall intensity, Long-term trend, Teleconnection.

\section{INTRODUCTION}

During the last decades there is an increasing evidence for more extreme rainfall at different places around the globe. Global warming was suggested to be linked with an increase in heavy rainfall due to an increase in atmospheric vapor and the warmer air. This trend is shown in the $4^{\text {th }}$ Assessment Report of the IPCC [1].

In general, the Mediterranean Basin shows decreasing trends in the precipitation amount [2-4]. The EM shows mixed rainfall trends but almost all stations show a decreasing trend in the precipitation which is especially large and significant during winter in the Greek, Cypriot and Turkish stations [5]. Precipitation reduction over most Greek stations, combined with enhanced anticyclonic activity over almost the whole Mediterranean was found during the late 1980s and the early 1990 s, a period characterized by high North Atlantic oscillation index values [6]. Time series of extreme precipitation cases in Greece for the period 1970-2002, did not reveal significant positive or negative trend [7].

Alpert et al. [8] showed the paradoxical increase of Mediterranean extreme daily rainfall in spite of the decrease in the total rainfall. They showed an increase in the torrential rainfall in Italy and Spain, heavy rainfall in Israel and heavytorrential rainfall over Cyprus for the period 1951-1995. These trends were significant only in Italy and Spain.

Kostopoulou and Jones [5] analyzed seasonal and annual trends over the central and Eastern Mediterranean (EM, 1958-2000). They showed statistically significant positive trends toward intense rainfall events and greater amount of precipitation for stations around the Italian Peninsula. For the EM, i.e., the Balkan Peninsula, western Turkey and

*Address correspondence to this author at the Department of Geography and the Human Environment, Tel-Aviv, University, Israel; Tel: +972-36406470; Fax: +972-3-6406243; E-mail: saaroni@post.tau.ac.il
Cyprus, they found negative trends in all precipitation indices.

Zhang et al. [9] examined several rainfall indices and emphasized that the precipitation regime in the Middle East is characterized by strong inter-annual variability without any significant trend in all of the precipitation indices for the period 1950-2003. This is in contrast to extreme temperature trends. In Israel, a significant warming trend was noted for the summer season $[10,11]$ whereas non-significant trends were found for the annual precipitation [8]. Several studies detected a decrease in precipitation in the last decades, primarily in the center and north of Israel, along with an increase in the southern region $[12,13]$.

Variations in precipitation are frequently explained by variations in atmospheric teleconnections, expressing the global or regional circulations. The most known teleconnections are the Southern Oscillation (SOI) related with the El Niño, and the North Atlantic Oscillation (NAO), being well correlated with the climate conditions over Europe and the Mediterranean, e.g. [14-16]. Winter precipitation over the EM was found to be well correlated with several teleconnections patterns. Price et al. [17] indicated on enhanced winter precipitation in Israel during El Niño years. Conte et al. [18] developed the Mediterranean Oscillation index (MOI) based on a seesaw that they found between Algiers and Cairo in the mean annual geopotential heights at the 500-hPa level. Based on this concept, a seesaw behavior of precipitation between the western and eastern Mediterranean was attributed to this oscillation e.g. [19, 20]. The North Sea-Caspian Sea Pattern (NCP), an upper level atmospheric teleconnection, was found also to affect the precipitation regimes in the EM [21-23]. This pattern has several similarities with the East Atlantic-Western Russia (EA/WR) oscillation, found to play an important role in the precipitation variations over the EM $[24,25]$. Kishcha et al. [26] showed that the combination of both positive EA/WR 
and positive NAO is highly related to positive rainfall anomaly over the southeastern Mediterranean.

The present study focuses on long-term trends in the distribution of daily rainfall intensities across Israel along with the trends of the total annual rainfall. The total rainfall and the rainfall for each intensity category were correlated with various teleconnection patterns in order to find out which circulation patterns may explain these tendencies.

\section{METHODOLOGY}

Based on [8], the six rainfall categories defined for the Mediterranean Basin, were used for the daily rainfall intensity in Israel. The daily rainfall categories are: Light (A) 0-4 mm/d; Moderate (B) $4-16 \mathrm{~mm} / \mathrm{d}$; Light to Moderate (A\&B) $0-16 \mathrm{~mm} / \mathrm{d}$ (the sum of $\mathrm{A}$ and $\mathrm{B}$ ); Moderate-Heavy (C1) $16-32 \mathrm{~mm} / \mathrm{d}$; Heavy (C2) $32-64 \mathrm{~mm} / \mathrm{d}$; HeavyTorrential (D1) $64-128 \mathrm{~mm} / \mathrm{d}$. Daily rain values in powers of 2, i.e. $2^{\mathrm{n}}$ as indicated above, allow the evaluation of the contribution of different rainfall categories to the rainfall totals and how this contribution changes in time [8].

The rainfall season in Israel is between October and May and $90 \%$ of the rainfall is concentrated in the mid-winter months, December-February [27]. We have analyzed the long-term trends of the annual rainfall for the period between $1950 / 1$ and 2003/4, based on the daily rainfall at 32 stations across Israel; for the location of the stations see Fig. (1a).

The linear trend is computed for the total annual rainfall and for each intensity category at each station. The significance of the linear trend (Pearson) as well as the monotone (Spearman's) non-linear time-tests is added. In order to better represent the variability in rainfall intensities we have studied also the non-linear trends of the rainfall intensities. In addition, we have applied the same methodology focusing on the three main regions in Israel: north, center and south varying in their average rainfall [27], where each region represents a cluster of stations (Fig. 1b). Each region is characterized by highly significant correlation in the rainfall distribution among the stations $(\mathrm{R}>0.9)$ based on cluster analysis of the correlation among the stations. For studying the spatial distribution of the trends, contour maps for the trends of the rainfall intensity categories and a map for the trends of the total annual rainfall were drawn. The results were normalized and are presented in percentages in order to compare between the stations and regions.

The total rainfall and the rainfall for each intensity

(b)
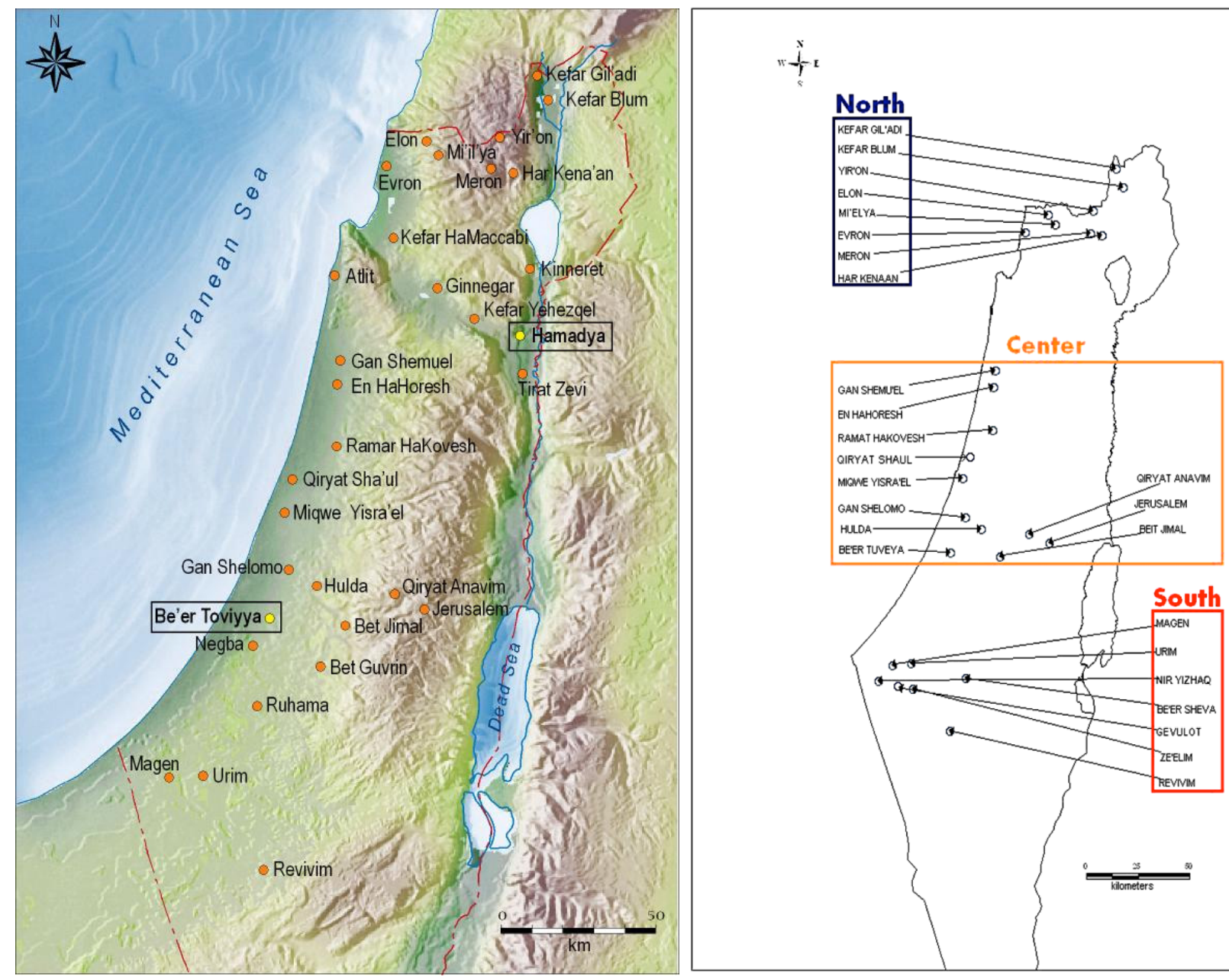

Fig. (1). (a) The 32 stations of the Israeli rainfall network. (b) The cluster of stations used to calculate the trends for the three regions: north, center and south. 
category were correlated with the following teleconnection patterns: NAO, EA/WR, MOI (I/G, Israel and Gibraltar and C/A, Cairo and Algiers), SOI, Nino 3, 4 and Nino 3-4 (Appendix A specifies the websites of the patterns). The correlation is performed between the total rainfall amount for each category (summed from the daily measurements) and the teleconnection indices. The indices used for the correlation were averaged over the entire rainfall season (October-May) and over the mid-winter months (DJF). The correlation was done on a regional scale (based on the clusters seen in Fig. 1b), i.e., for the north, center and south regions of Israel.

\section{RESULTS}

First, we examined the annual trend of the total rainfall in all the stations. In contrast to former studies [12, 13] that show a decrease in the rainfall amount until the early 90 s, we have found a general, non-significant increase in the total rainfall for the study period and a non-significant decrease is noted at the northeastern region (Fig. 2). The trend was found significant $(p \leq 0.05)$ only in Be'er Toviyya station, representing the southern coastal region, an increase of $5.3 \%$ per decade. Kutiel et al. [22] found that rainfall in Israel during the positive phase of NCP is by far greater than the rainfall during the negative phase of $\mathrm{NCP}$, and that the effect of NCP on the rainfall regime in Israel increases from the northern parts of the country to the south. Indeed, we found higher correlations between the total annual rainfall and the $\mathrm{NCP}$ and EA/WR for the center and south regions, in agreement with $[22,24,25]$, though being significant also for the north (Table 2). Note that the correlation with the $\mathrm{NAO}$ is being significant mainly for the center and south.

Fig. (3) summarizes the significant daily trends found in specific stations, according to the intensity categories. An increase in the moderate-heavy till heavy-torrential categories can be noticed in some stations, whereas in other stations the increase is in the light to moderate category. Some stations show an increase in the heavy category together with a decrease in the light to moderate one (e.g. Be'er Toviyya and Ramat Hakovesh). An opposite trend, i.e., an increase in the light to moderate category and a decrease in the heavy and heavy-torrential ones, is noted farther north in Bet She'an/Izrael Valley (demonstrated by KefarYehezqel and Hamadya stations) and in the Upper Galilee mountains (demonstrated by Meron station), both belonging to the north region of Israel. The trends found significant for each of the daily rainfall categories are summarized in Table 1.

Another way to express the change is by comparing the number of rainy days for each category at the beginning against the end of the study period. For example, the average number of rainy days in Jerusalem for category D1 was at the beginning of the $50 \mathrm{~s} 0.5 \mathrm{~d} / \mathrm{y}$, while in the $2000 \mathrm{~s}$ it increased to $1.25 \mathrm{~d} / \mathrm{y}$. An opposite example was found in Meron (Upper Gallilee Mountains), where during the 50s the average number for this category was $3.25 \mathrm{~d} / \mathrm{y}$ and in the $2000 \mathrm{~s}$ it dropped to $1.5 \mathrm{~d} / \mathrm{y}$. It should be emphasized that an opposite's significant trend, as shown, was recorded only in five out of the 32 studied stations.

Fig. (4) presents the spatial distribution trends for two of the categories: (3a) light-moderate $(\mathrm{A} \& \mathrm{~B})$ and $(\mathbf{3 b})$ heavy
(C2). For $\mathrm{A} \& \mathrm{~B}$ a significant negative trend along the southern coastal plain and a significant positive trend at northeast Israel, Bet She'an/Izrael Valley, can be noticed. In contrast, for $\mathrm{C} 2$, a significant positive trend is seen along the southern coastal plain and a negative trend at the Bet She'an/Izrael Valley. An increased tendency toward heavier rainfall in the central and southern parts of Israel is seen.

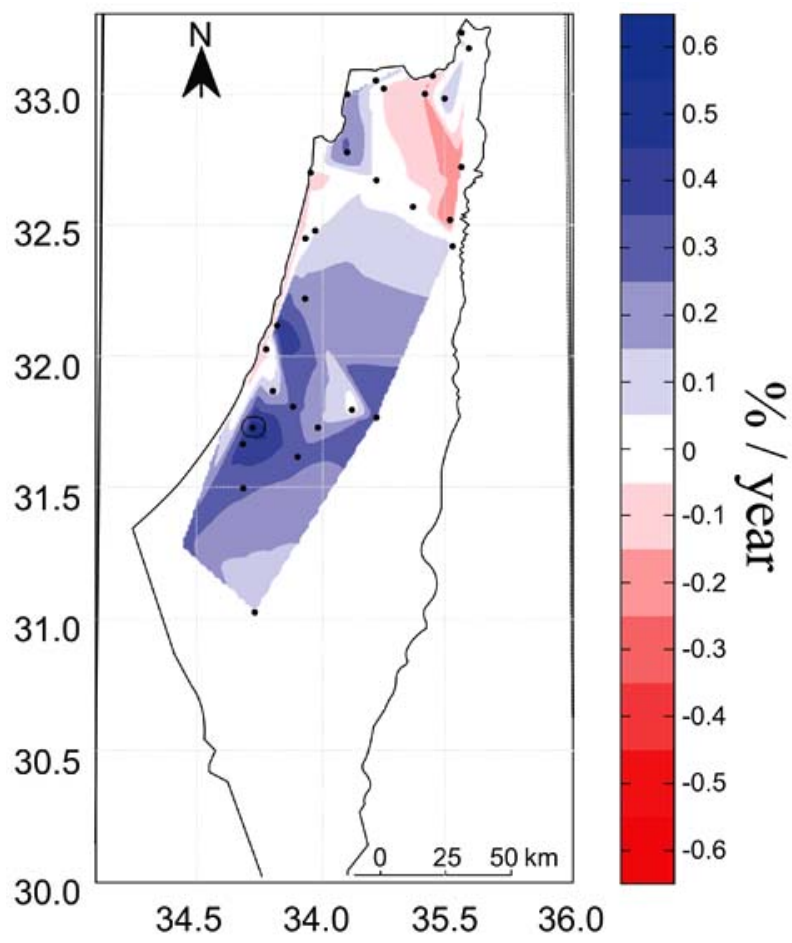

Fig. (2). The trend of the total rainfall (\%/year) for the period 1950/1-2003/4.

Beyond the trends of each of the rainfall categories studied for the 32 stations (the significant results are presented in Fig. 3) these trends are studied also on a regional basis, for the three regions (Fig. 5). Category A\&B (light to moderate) is the highest rainfall contributor, $\sim 35 \%$ in the north and center and $>65 \%$ in the south. In the north and center, the second contributors are $\mathrm{C} 1$ and $\mathrm{B}$ (moderateheavy, and moderate), $29 \%$ and $34 \%$, respectively. Next in these regions is the heavy category, C2, which contributes $25 \%-28 \%$ of the total rainfall. Then, comes D1 (heavytorrential) with $6 \%-8 \%$ and the light category, A, with approximately $7 \%$. For the south, the results are different; B (moderate) is the second rainfall contributor $\sim 50 \%$ and $\mathrm{C} 1$ afterwards, $26 \%$. Next is A, about $16 \%$ while $\mathrm{C} 2$, the highest intensity in the south, contributes $10 \%$.

The slope of the long-term trend indicates a decrease in the light to moderate categories at the center and south against an increase in the intense categories (C2 and D1 in the center and $\mathrm{C} 2$ in the south), whereas the trends found at the north are opposite, i.e. increase in the light to moderate categories against a decrease in the heavy to torrential categories. It should be noted that the trends that were found to be significant $(p<0.1)$ are only in category $\mathrm{C} 1$ for the 


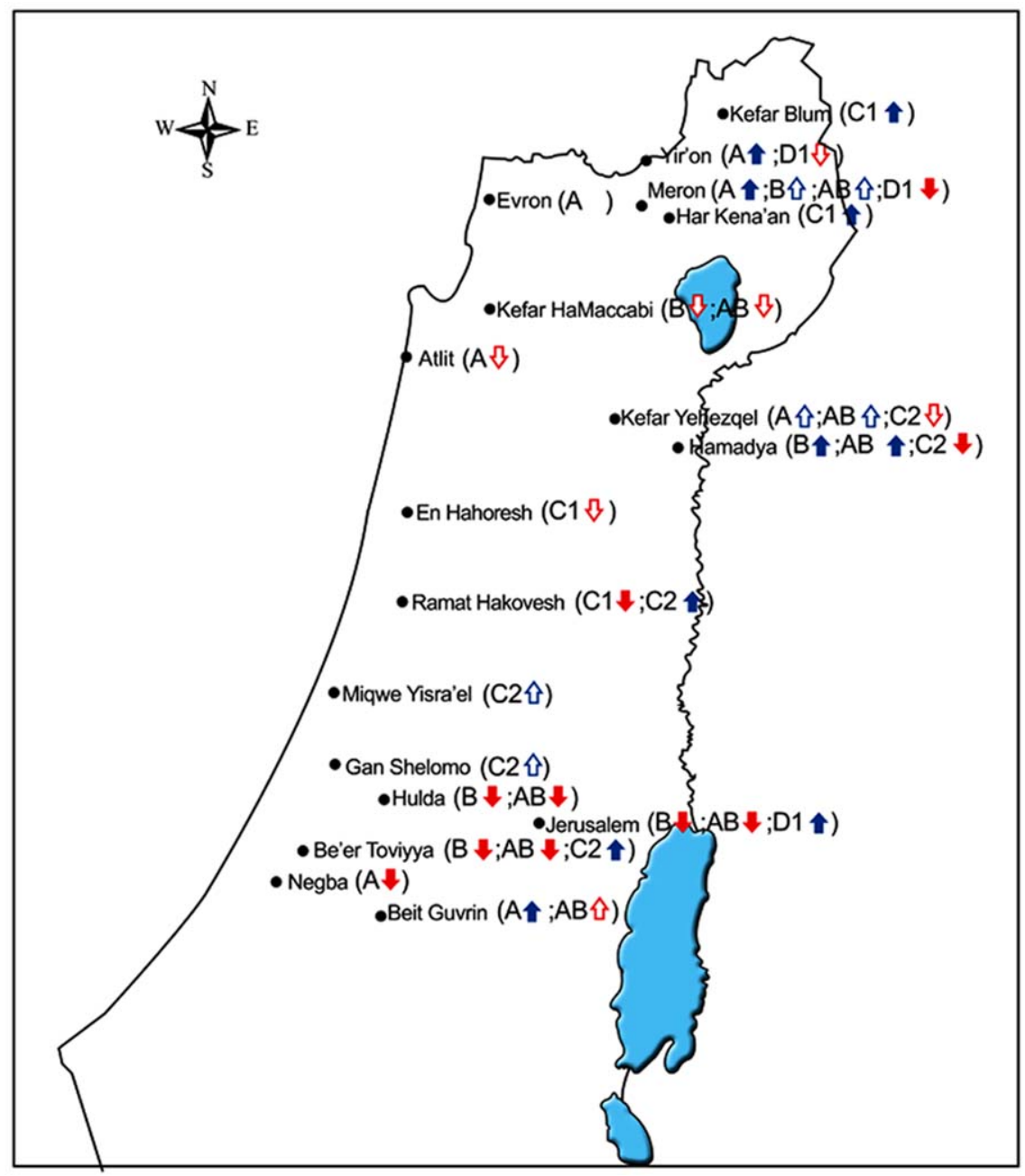

Fig. (3). Significant trends for the different categories of daily rainfall intensity. The arrows show the trend direction, positive (red, upward) or negative (blue, downward). Bold (full) arrow ( level.

Table 1. Comparison Between the Rainfall Percentage from the Annual in the 1950s and the 2000s (According the Significant Linear Trend of Each Category, Not Shown) for the 5 Stations having an Opposite Significant Trends. Stations are Listed from North Towards the South. See Figs. (1a, 3) for their Location

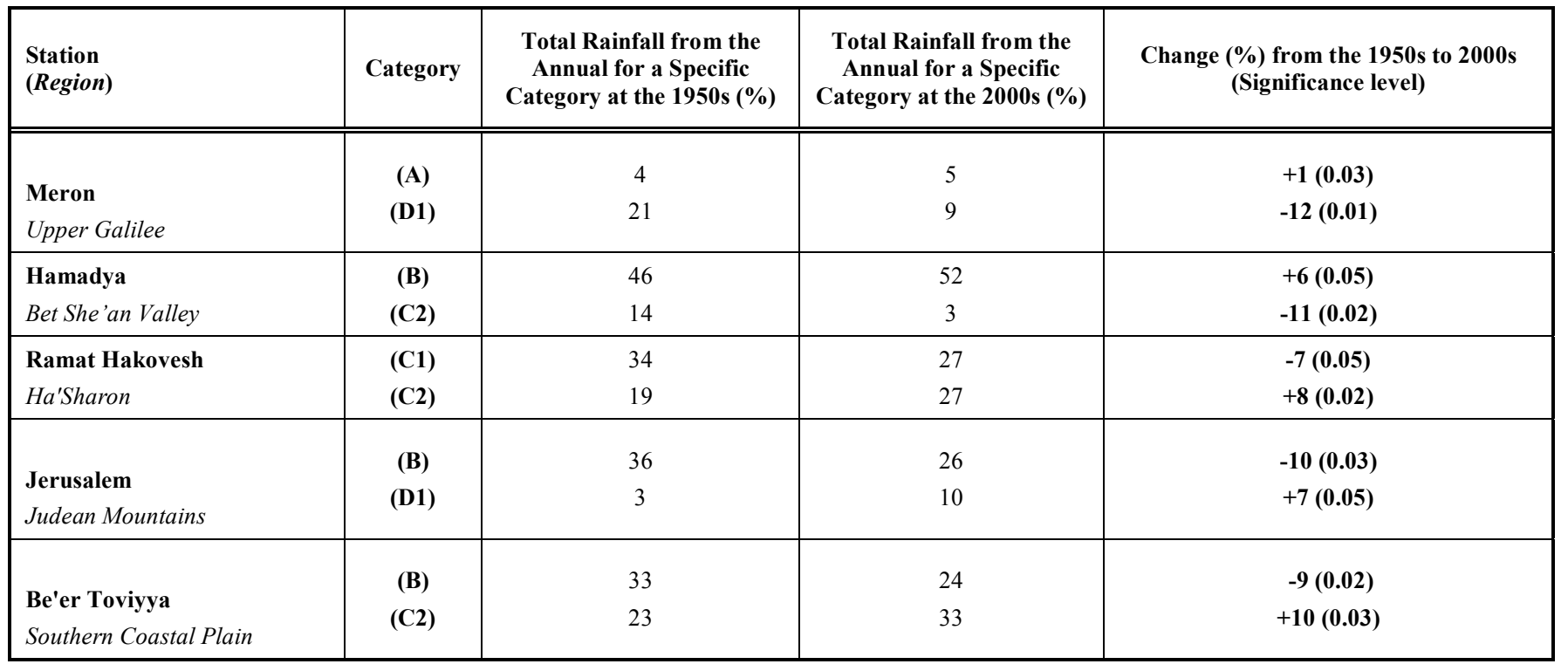




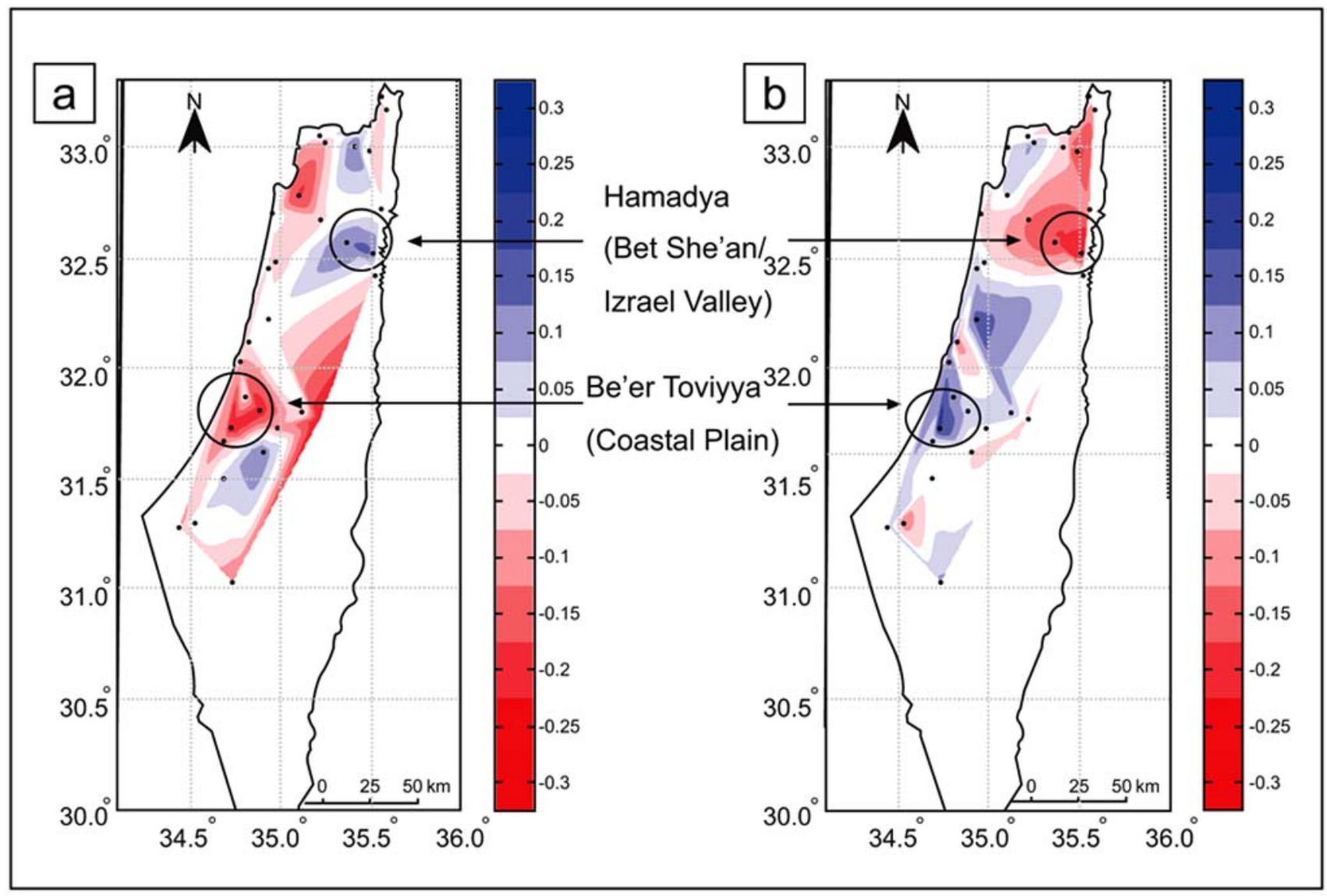

Fig. (4). The spatial distribution of the trends in the light to moderate, A\&B (a) and heavy C2 (b) categories (\%/year). Areas having significant trends are circled.

north and C2 for the center. The center and the south show similarity in their trends, mostly opposite to those of the north. In the light to moderate categories, the trends in the center and the south are negative while the heavy category (C2) showed a sharp increase, three times larger compared to the north.

The total rainfall and the rainfall for each intensity category were correlated with a wide range of teleconnection patterns. Table 2 summarizes the significant correlations ( $p \leq 0.05$ and $p \leq 0.1$ ) found for each of the three regions. Significant positive correlations $(p \leq 0.05)$ for all rainfall categories as well as the total rainfall were found with the NCP and the EA/WR indices. The correlation was found significant both for the indices calculated for the entire winter (November-March) and higher with the indices calculated for the mid-winter (December-February, Table 2). The highest correlations are for the center and the lowest for the north, in agreement with [22] who pointed at the increased influence of NCP on the center and south regions of Israel. As expected, most similar results are found for the EA/WR pattern [24, 25]. For the total rainfall, significant correlations $(p \leq 0.1)$ were found with the SOI, Nino 3, Nino 4 and Nino 3-4 - but only in the north and center. Some significant correlations were found also with the MOI indices ( $\mathrm{I} / \mathrm{G}$ and $\mathrm{C} / \mathrm{A})$, especially in the south and only with part of the rainfall categories. Regarding the NAO, a positive significant correlation was found with the total rainfall in the center and south and with some of the rainfall categories (Table 2).

\section{SUMMARY}

Studies have shown a general decrease in the total rainfall during the last decades in the Mediterranean basin $[2-4,5]$ including Israel $[12,13]$, in contrast to the increase in the contribution of intense rainfall that is found significant in part of the region [8].

This study examined six daily rainfall categories for the period 1950/1-2003/4, based on 32 stations across Israel. It is shown that a significant increase in the heavy to torrential daily rainfall occurred in some stations although no significant change is seen in the annual rainfall. For Instance, over the southern coastal plain of Israel (Be'er Toviyya), heavy rainfall contributed approximately $23 \%$ of the annual rainfall in the $1950 \mathrm{~s}$ comparing to $33 \%$ in the $2000 \mathrm{~s}$ whereas, the moderate rainfall showed a significant decrease from $33 \%$ to $24 \%$, respectively. An opposite significant trend, i.e. an increase in the light to moderate category and a decrease in the heavy one was found at some northern stations (e.g., Hamadya). An increase in the moderate-heavy (C1) category and a decrease in the heavy and heavy to torrential ones (C2 and D1) is found in the north, whereas in the center the contribution of the heavy category $(\mathrm{C} 2)$ rose from $23 \%$ to $27 \%$. The computed increase in $\mathrm{C} 2$ category in the south is from $8 \%$ to $12 \%$ (computed for the 35 years that 

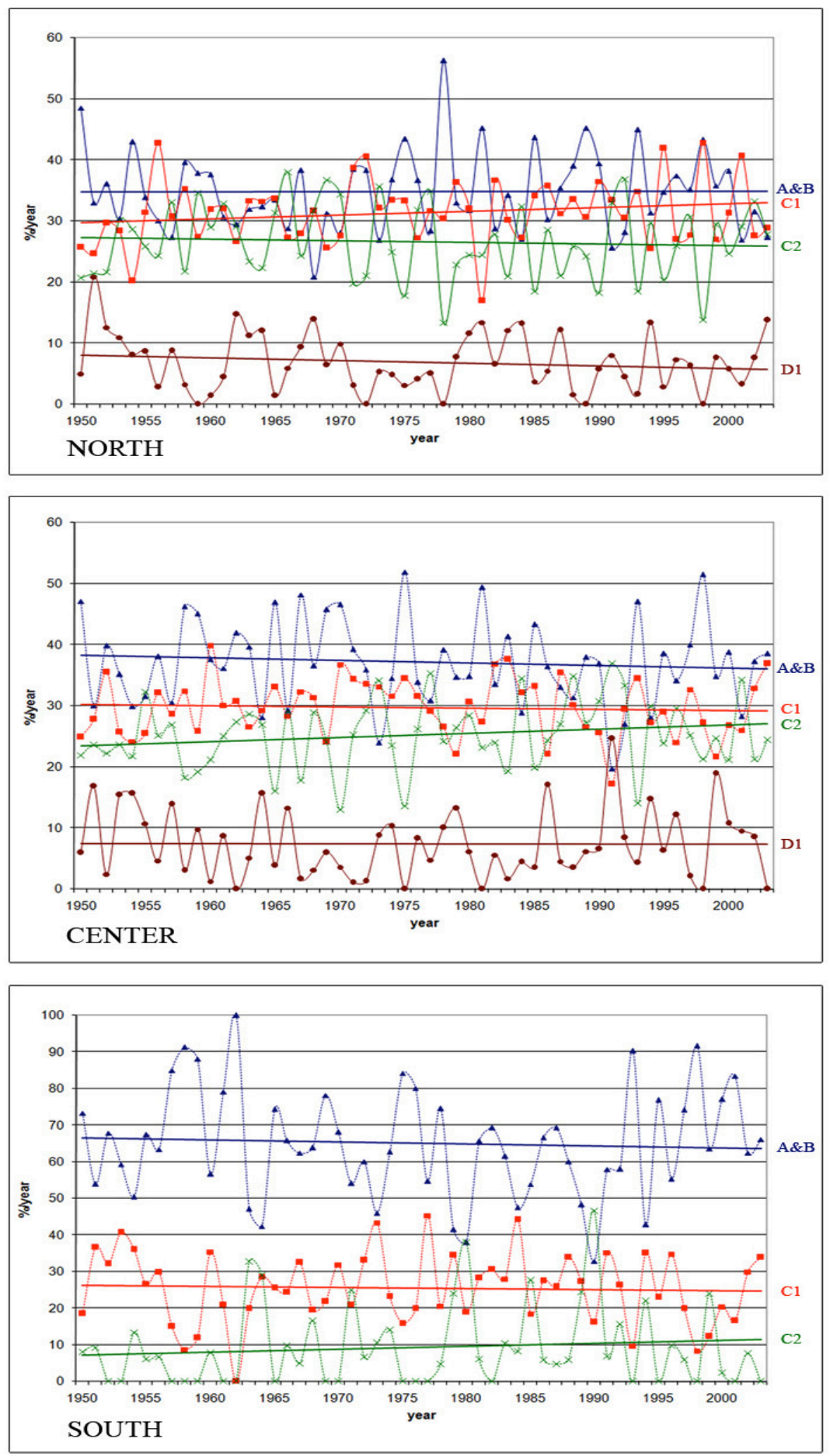

\begin{tabular}{|c|c|c|c|}
\hline $\begin{array}{c}\text { Category } \\
\text { (North } \\
\text { region) }\end{array}$ & $\begin{array}{c}\text { Intensity } \\
(\mathrm{mm} / \mathrm{d})\end{array}$ & $\begin{array}{c}\text { Linear } \\
\text { Trend } \\
\% / 10 \mathrm{y} \\
(\text { Sig. })\end{array}$ & $\begin{array}{c}\text { Significance } \\
\text { of the } \\
\text { monotone } \\
\text { non-linear } \\
\text { time-test }\end{array}$ \\
\hline A & $0-4$ & $\begin{array}{c}0.17 \\
(0.124)\end{array}$ & $(0.135)$ \\
\hline B & $4-16$ & $\begin{array}{c}-0.13 \\
(0.39)\end{array}$ & $(0.399)$ \\
\hline A\&B & $0-16$ & $\begin{array}{c}0.04 \\
(0.477)\end{array}$ & $(0.491)$ \\
\hline C1 & $16-32$ & $\begin{array}{c}0.6 \\
(0.096)\end{array}$ & $(0.125)$ \\
\hline C2 & $32-64$ & $\begin{array}{c}-0.26 \\
(0.312)\end{array}$ & $(0.375)$ \\
\hline D1 & $64-128$ & $\begin{array}{c}-0.44 \\
(0.141)\end{array}$ & $(0.225)$ \\
\hline
\end{tabular}

\begin{tabular}{|c|c|c|c|}
\hline $\begin{array}{c}\text { Category } \\
\text { (Center } \\
\text { region) }\end{array}$ & $\begin{array}{c}\text { Intensity } \\
(\mathrm{mm} / \mathrm{d})\end{array}$ & $\begin{array}{c}\text { Linear } \\
\text { Trend } \\
\% / 10 \mathrm{y} \\
(\text { Sig. })\end{array}$ & $\begin{array}{c}\text { Significance } \\
\text { of the } \\
\text { monotone } \\
\text { non-linear } \\
\text { time-test }\end{array}$ \\
\hline A & $0-4$ & $\begin{array}{c}-0.16 \\
(0.188)\end{array}$ & $(0.145)$ \\
\hline B & $4-16$ & $\begin{array}{c}-0.27 \\
(0.293)\end{array}$ & $(0.305)$ \\
\hline A\&B & $0-16$ & $\begin{array}{c}-0.43 \\
(0.25)\end{array}$ & $(0.271)$ \\
\hline C1 & $16-32$ & $\begin{array}{c}-0.21 \\
(0.306)\end{array}$ & $(0.442)$ \\
\hline C2 & $32-64$ & $\begin{array}{c}0.67 \\
(0.085)\end{array}$ & $(0.085)$ \\
\hline D1 & $64-128$ & $\begin{array}{c}-0.03 \\
(0.479)\end{array}$ & $(0.445)$ \\
\hline \multicolumn{3}{|c|}{} \\
\multicolumn{2}{|c|}{}
\end{tabular}

\begin{tabular}{|c|c|c|c|}
\hline $\begin{array}{c}\text { Category } \\
\text { (South } \\
\text { region) }\end{array}$ & $\begin{array}{c}\text { Intensity } \\
(\mathrm{mm} / \mathrm{d})\end{array}$ & $\begin{array}{c}\text { Linear } \\
\text { Trend } \\
\% / 10 \mathrm{y} \\
(\text { Sig. })\end{array}$ & $\begin{array}{c}\text { Significanc } \\
\text { e of the } \\
\text { monotone } \\
\text { non-linear } \\
\text { time-test }\end{array}$ \\
\hline A & $0-4$ & $\begin{array}{c}-0.4 \\
(0.227)\end{array}$ & $(0.37)$ \\
\hline B & $4-16$ & $\begin{array}{c}-0.16 \\
(0.441)\end{array}$ & $(0.479)$ \\
\hline A\&B & $0-16$ & $\begin{array}{c}-0.55 \\
(0.339)\end{array}$ & $(0.4)$ \\
\hline C1 & $16-32$ & $\begin{array}{c}-0.3 \\
(0.364)\end{array}$ & $(0.304)$ \\
\hline C2 & $32-64$ & $\begin{array}{c}0.79 \\
(0.208)\end{array}$ & $(0.285)$ \\
\hline
\end{tabular}

Fig. (5). The trend of the rainfall contribution as percentage from the total amounts for each of the daily rainfall categories: A\&B, C1, C2, D1, for the period 1950/1-2003/4. Upper panel-North, central panel-Center and lower panel-South. The corresponding symbols are: A\&B $(\boldsymbol{\Delta}), \mathrm{C} 1(\mathbf{\square}), \mathrm{C} 2(\mathbf{X}), \mathrm{D} 1(\mathbf{O})$. The linear trend and significance and the significance of the monotone non-linear time-test are added for each of the rainfall categories.

rain was measured in this category). Nevertheless, in the first half of the study period (1951-1977) there were 13 years with no rainfall in category $\mathrm{C} 2$ compared to only 6 years in the second half (1978-2004), further indicating the difference between the periods (Fig. 5).

It was speculated that the tendency towards heavier rainfall at the southern coastal plain (Be'er Toviyya station) may be associated with the significant increase in the frequency of the Red-Sea trough since the 1960s [28], responsible for heavy rainfall, especially in the south and east regions of Israel [29]. In order to validate this hypothesis we have checked the synoptic type of each rain day in the heavy rainfall categories, C2 and D1, in Be'er Toviyya station. The synoptic identification is based on the semi-objective classification [28]. It was found that all 
Table 2. Significant Correlations $(R)$ (at the $p \leq 0.05$ bold, and at the $p \leq 0.1$ ) Between the Annual Rainfall for Each Category and the Teleconnection Patterns (Calculated for DJF), for the North (N), Center (C) and South (S) Regions of Israel. The Coefficients $(R)$ are Added in Brackets

\begin{tabular}{|c|c|c|c|c|c|c|c|}
\hline Rainfall Category/Index & $\mathbf{A}$ & B & A\&B & C1 & $\mathrm{C} 2$ & D1 & Total Rainfall \\
\hline NAO & $\mathrm{N}(0.19)$ & $\mathrm{S}(0.19)$ & $\mathrm{S}(0.19)$ & $\begin{array}{l}C(0.23) \\
S(0.25)\end{array}$ & $\begin{array}{c}\mathrm{C}(0.2) \\
\mathrm{S}(0.19)\end{array}$ & & $\begin{array}{c}\mathrm{C}(0.2) \\
\mathbf{S}(\mathbf{0 . 2 9 )}\end{array}$ \\
\hline MOI (C/A) & & & & $\begin{array}{l}\mathrm{C}(0.22) \\
\mathbf{S}(\mathbf{0 . 2 6})\end{array}$ & $\mathrm{C}(\mathbf{0 . 3 4})$ & $\mathrm{C}(\mathbf{0 . 3 5})$ & $\begin{array}{l}C(0.32) \\
S(0.28)\end{array}$ \\
\hline $\operatorname{MOI}(\mathrm{I} / \mathrm{G})$ & & & & $\mathrm{S}(0.22)$ & & $\mathrm{C}(\mathbf{0 . 2 6})$ & $\mathrm{S}(0.22)$ \\
\hline EA/WR & $\begin{array}{c}\mathrm{N}(0.4) \\
\mathrm{C}(0.42) \\
\mathrm{S}(0.45)\end{array}$ & $\begin{array}{l}\mathrm{N}(0.27) \\
\mathrm{C}(0.35) \\
\mathrm{S}(\mathbf{0 . 3 8})\end{array}$ & $\begin{array}{c}\mathrm{N}(\mathbf{0 . 3 )} \\
\mathrm{C}(0.39) \\
\mathrm{S}(\mathbf{0 . 4 3 )}\end{array}$ & $\begin{array}{c}\mathrm{N}(0.4) \\
\mathrm{C}(0.29) \\
\mathrm{S}(0.3)\end{array}$ & $\begin{array}{l}N(0.28) \\
C(0.45)\end{array}$ & $\mathrm{C}(\mathbf{0 . 3 7})$ & $\begin{array}{c}\mathrm{N}(0.33) \\
\mathrm{C}(0.48) \\
\mathrm{S}(0.4)\end{array}$ \\
\hline $\mathrm{NCP}$ & $\begin{array}{c}N(0.3) \\
C(0.47) \\
S(0.45)\end{array}$ & $\begin{array}{l}\mathrm{N}(0.23) \\
\mathrm{C}(0.33) \\
\mathrm{S}(0.34)\end{array}$ & $\begin{array}{c}N(0.26) \\
C(0.38) \\
S(0.4)\end{array}$ & $\begin{array}{l}N(0.43) \\
C(0.36) \\
S(0.38)\end{array}$ & $\begin{array}{l}\text { N (0.25) } \\
\text { C (0.49) } \\
S(0.22)\end{array}$ & $\mathrm{C}(\mathbf{0 . 2 3})$ & $\begin{array}{l}\text { N (0.34) } \\
C(0.47) \\
S(0.46)\end{array}$ \\
\hline SOI & $\begin{array}{l}\mathrm{N}(-0.19) \\
\mathrm{S}(-0.19)\end{array}$ & $\begin{array}{l}\text { N (-0.28) } \\
\mathrm{C}(-0.31)\end{array}$ & $\begin{array}{l}\mathrm{N}(-0.28) \\
\mathrm{C}(-0.29)\end{array}$ & $\begin{array}{c}\mathrm{N}(-0.4) \\
\mathrm{C}(-0.31)\end{array}$ & $\begin{array}{l}\text { N (-0.32) } \\
C(-0.3)\end{array}$ & $\begin{array}{l}\text { N (-0.22) } \\
C(-0.23)\end{array}$ & $\begin{array}{c}N(-0.4) \\
C(-0.36)\end{array}$ \\
\hline NINO 3 & $\mathrm{~N}(0.18)$ & $\begin{array}{l}\mathrm{N}(0.21) \\
\mathbf{C}(\mathbf{0 . 2 5})\end{array}$ & $\begin{array}{l}\mathrm{N}(0.22) \\
\mathbf{C}(\mathbf{0 . 2 3}) \\
\mathrm{S}(0.18)\end{array}$ & $\begin{array}{l}N(0.28) \\
C(0.23)\end{array}$ & $\begin{array}{c}\mathbf{N}(\mathbf{0 . 2 9}) \\
\mathrm{C}(0.2)\end{array}$ & & $\begin{array}{c}\mathrm{N}(\mathbf{0 . 3 )} \\
\mathrm{C}(\mathbf{0 . 2 5})\end{array}$ \\
\hline NINO 4 & $\begin{array}{l}\mathrm{N}(0.26) \\
\mathrm{S}(\mathbf{0 . 2 4 )}\end{array}$ & $\begin{array}{l}\mathrm{N}(0.29) \\
\mathrm{C}(0.34)\end{array}$ & $\begin{array}{c}\mathrm{N}(0.3) \\
\mathrm{C}(\mathbf{0 . 3 2})\end{array}$ & $\begin{array}{l}\text { N (0.39) } \\
C(0.24)\end{array}$ & $\begin{array}{l}\mathrm{N}(0.32) \\
\mathrm{C}(0.26)\end{array}$ & $\mathrm{N}(\mathbf{0 . 2 2})$ & $\begin{array}{c}N(0.39) \\
C(0.3)\end{array}$ \\
\hline NINO_3-4 & $\begin{array}{l}\mathrm{N}(0.2) \\
\mathrm{S}(0.21)\end{array}$ & $\begin{array}{l}\mathbf{N}(\mathbf{0 . 2 7}) \\
\mathbf{C}(\mathbf{0 . 3 1}) \\
\mathrm{S}(0.18)\end{array}$ & $\begin{array}{l}\text { N (0.27) } \\
\mathbf{C}(\mathbf{0 . 3 )} \\
\mathrm{S}(0.2)\end{array}$ & $\begin{array}{l}N(0.36) \\
C(0.25)\end{array}$ & $\begin{array}{l}\text { N (0.35) } \\
C(0.27)\end{array}$ & $\begin{array}{c}\mathrm{N}(0.2) \\
\mathrm{C}(\mathbf{0 . 2 2})\end{array}$ & $\begin{array}{l}\mathrm{N}(\mathbf{0 . 3 8}) \\
\mathrm{C}(\mathbf{0 . 3 2})\end{array}$ \\
\hline
\end{tabular}

torrential rainfall days with D1 intensities were associated with Cyprus Lows. Moreover, only $6 \%$ of the days with $\mathrm{C} 2$ intensity were associated with Red-Sea Trough and no increase in their occurrence is found in the study period.

Israel is located on a climatic border, between the temperate and the arid regions subjected to severe water shortage. Thus, the finding shown in this study has to be carefully followed since the region is predicted to dry-up in most global warming scenarios [1].

\section{ACKNOWLEDGEMENTS}

The study was supported by the Israeli Science Foundation (ISF, 764/06), the Porter School of Environmental Studies, Tel-Aviv University, the GLOWAJordan River BMBF-MOS and the EU-CIRCE projects. Thanks to the Israeli Meteorological Service for providing the rainfall data, to Dr. Orna Zafrir and to Ms. Oksana Stalnov for helping in drawing Figs. $(\mathbf{1 a}, \mathbf{2}, \mathbf{4})$.

\section{APPENDIX}

The web-sites of the teleconnection patterns

NAO: ftp://ftp.cpc.ncep.noaa.gov/wd52dg/data/indices/tele_index.nh

EA/WR: ftp://ftp.cpc.ncep.noaa.gov/wd52dg/data/indices/tele_index.nh

MOI (I/G, Israel and Gibraltar and C/A, Cairo and Algiers): http://www.cru.uea.ac.uk/cru/data/moi/

NCP: http://www.cru.uea.ac.uk/ andrewh/ncp.html

SOI: http://www.bom.gov.au/climate/current/soihtm1.shtml

Nino 3, 4 and Nino 3-4: http://www.cpc.noaa.gov/data/indices/sstoi.indices 


\section{REFERENCES}

[1] Intergovernmental Panel on Climate Change. The Physical Science Basis, Summary for Policymakers. New York, Cambridge: Cambridge University Press 2007.

[2] Piervitali E, Colacino M, Conte M. Rainfall over the centralwestern Mediterranean Basin in the period 1951-1995, Part I: Precipitation trends. Nuovo Climentoc 1998; C21: 331-44

[3] Xoplaki E, Luterbacher J, Burkard R, Patrikas I, Maheras P. Connection between the large-scale $500-\mathrm{hPa}$ geopotential height fields and precipitations over Greece during wintertime. Clim Res 2000; 14: 129-46.

[4] Paz S, Steinberger EH, Kutiel H. Recent changes in precipitation patterns along the coast of the Eastern Mediterranean. Proceeding of the 2nd European Conference on Applied Climatology, Vienna, Austria 1998

[5] Kostopoulou E, Jones PD. Assessment of climate extremes in the Eastern Mediterranean. Meteorol Atmos Phys 2005; 89: 69-85.

[6] Bartzokas A, Lolis CJ, Metaxas DA. The 850-hPa relative vorticity centres of action for winter precipitation in the Greek area. Int $\mathbf{J}$ Climatol 2003; 23: 813-28.

[7] Houssos EE, Lolis CJ, Bartzokas A. Atmospheric circulation patterns associated with extreme precipitation amounts in Greece. Adv Geosci 2008; 17: 5-11.

[8] Alpert P, Ben-Gai T, Baharad A, et al. The paradoxical increase of Mediterranean extreme daily rainfall in spite of decrease in total values. Geophys Res Lett 2002; 29(11): 311-14.

[9] Zhang X, Aguilar E, Sensoy S, et al. Trends in middle east climate extreme indices from 1950 to 2003. J Geophys Res 2005; 110: D22104.

[10] Saaroni H, Ziv B, Edelson J, Alpert P. Long-term variations in summer temperatures over the Eastern Mediterranean. Geophys Res Lett 2003; 30(18): 1946, DOI: 10.1029/2003GL017742.

[11] Ziv B, Saaroni H, Baharad A, Yekutieli D, Alpert P. Indications for aggravation in summer heat conditions over the Mediterranean Basin. Geophys Res Lett 2005; 32(12): L12706 DOI:10.1029/2005GL022796

[12] Steinberger EH, Gazit-Yaari N. Recent changes in spatial distribution on annual precipitation in Israel. J Climate 1996; 9: 3328-36.

[13] Ben-Gai T, Bitan A, Manes A, Alpert P, Rubin S. Spatial and temporal changes in annual rainfall frequency distribution patterns in Israel. Theor Appl Climatol 1998; 61: 177-90.

[14] Wallace J, Gutzler D. Teleconnections in the geopotential height field during the Northern Hemisphere winter. Mon Wea Rev 1981; 109: 784-812.
[15] Barnston AG, Livezey RE. Classification, seasonality and persistence of low-frequency atmospheric circulation patterns. Mon Wea Rev 1987; 115: 1083-126.

[16] Hurrell JW. Decadal trends in the North Atlantic oscillation: regional temperatures and precipitation. Science 1995; 269: 676-9.

[17] Price C, Stone L, Rajagopalan B, Alpert P. A possible link between El Nino and precipitation in Israel. Geophys Res Lett 1998; 25: 3963-6.

[18] Conte M, Giuffrida A, Tedesco S. The Mediterranean oscillation. Impact on precipitation and hydrology in Italy. Proceeding of the Conference on Climate. The Academy of Finland, Helsinki, Finland, 1989; pp. 121-37.

[19] Kutiel H, Maheras P, Guika S. Circulation indices over the Mediterranean and Europe and their relationship with rainfall conditions across the Mediterranean. Theor Appl Climatol 1996; 54: $125-38$.

[20] Kutiel H, Paz S. Sea level pressure departures in the Mediterranean and their relationship with monthly rainfall conditions in Israel. Theor Appl Climatol 1998; 60: 93-109.

[21] Kutiel H, Benaroch Y. North Sea-Caspian pattern (NCP) - an upper level atmospheric teleconnection affecting the eastern Mediterranean: identification and definition. Theor Appl Climatol 2002; 71: 17-28.

[22] Kutiel H, Maheras P, Türkes M, Paz S. North Sea Caspian pattern (NCP) - an upper level atmospheric teleconnection affecting the eastern Mediterranean: implications on the regional climate. Theor Appl Climatol 2002; 72: 173-92.

[23] Kutiel H, Türkeş M. New evidence for the role of the North Sea Caspian pattern on the temperature and precipitation regimes in continental central Turkey. Geogr Ann Seri A Phys Geogra 2005; 87(4): 501-13.

[24] Krichak SO, Kishcha P, Alpert P. Decadal trends of main Eurasian oscillations and the Mediterranean precipitation. Theor Appl Climatol 2002; 72: 209-20.

[25] Krichak SO, Alpert P. Decadal trends in the East Atlantic-West Russia pattern and Mediterranean precipitation. Int $\mathrm{J}$ Climatol 2005; 25: 183-92.

[26] Kishcha P, Barkan J, Alpert P. Decadal variations in wind anomalies over the Eastern Mediterranean and precipitation in Israel. Judea Samaria Res Stud 2003; 12: 379-89 (in Hebrew).

[27] Goldreich Y. The climate of Israel: Observation, research and application. UK: Kluwer Academic/Plenum Publishers 2003.

[28] Alpert P, Osetinsky I, Ziv B, Shafir H. Semi-objective classification for daily synoptic systems: application to the Eastern Mediterranean climate change. Int J Climatol 2004; 24: 1001-11.

[29] Kahana R, Ziv B, Enzel Y, Dayan U. Synoptic climatology of major floods in the Negev desert, Israel. Int J Climatol 2002; 22: $867-82$. 